\title{
Re-Creating Nostalgia: Urban Culture in the Citadel, Hamamönü and Hamamarkası Neighbourhoods of
} Ankara

\author{
Nostaljiyi Yeniden Yaratmak: Ankara’nın Kale, Hamamönü ve \\ Hamamarkası Mahallelerinde Kent Kültürü
}

\section{Petek ONUR}

Dr., Bağımsız Araştırmacı

petekonur@yahoo.com.tr

DOI: $10.5505 /$ jas.2018.41713

\begin{abstract}
Conservation, renovation, restoring and urban regeneration activities have been carried out in the historic centre of Ankara, in Ankara Citadel since 2007 and right beside it, in Hamamönü both by local government and investors from the public sector and small-scale enterprises. Hamamarkas1 region has been the last episode of this process. These activities construct spaces for the consumption and demands of the tourists as well as urban travellers and create a new nostalgia culture based on the phenomenon of authenticity by means of aestheticisation practices. Local ties of belonging which weaken with modernization of globalization come to the fore again and become determining in the production and consumption phases of nostalgia culture.

The aim of this study is to examine the formation of the nostalgia culture in these historic regions of Ankara and the diversities that have been produced within it by several actors. Based on the fieldwork comprising the enterprises like cafés, restaurants, antique shops, art galleries, art studios, boutique hotels in the regions, the study presents the repercussions of social memory, traditions, perceptions and longings of the past in the urban culture of Ankara. In the light of these data, it is seen that in these three regions different nostalgia cultures are formed and the emerging cultures are both influenced by neo-liberal globalization and the prevailing political dynamics in Turkey, particularly by the policy of neo-Ottomanism which has been effective in the last ten years.
\end{abstract}

Keywords: Nostalgia, Authenticity, Aestheticisation, Urban conservation, Urban regeneration, Urban culture, Hamamönü, Hamamarkası, Ankara citadel, Ankara

\section{$\ddot{O} z$}

Ankara'nn tarihî merkezi olan Ankara Kale'sinde 1980'lerin sonundan beri ve hemen yakınndaki Hamamönü’nde ise 2007'den beri hem yerel yönetimler hem de özel sektörden yatırımclar ve küçük işletmeler tarafindan koruma, renovasyon, restorasyon ve kentsel dönüşüm faaliyetleri sürdürülmektedir. Hamamarkası bölgesi ise bu sürecin son halkasın oluşturmaktadır. Bu faaliyetler hem turistlerin hem de kent gezginlerinin tüketimine ve taleplerine yönelik mekânlar inşa etmekte ve otantiklik olgusundan yola çıarak ve estetikleştirme pratikleri aracilğ̌yla yeni bir nostalji kültürü yaratmaktadır. Modernleşme ve küreselleşmeyle birlikte zayıflayan yerel aidiyet bağları da nostalji aracılğglyla tekrar gündeme gelmekte ve nostalji kültürünün hem üretim hem de tüketim aşamalarında belirleyici olmaktadir.

* This article is based on the research "Re-creating Nostalgia in Citadel and Hamamönü Neighbourhoods of Ankara" funded by Yüksel Erimtan Culture and Arts Foundation.

** Bu makale, Yüksel Erimtan Kültür ve Sanat Vakfı̉nın desteğiyle gerçekleştirilmiş olan "Ankara’nın Kale ve Hamamönü Semtlerinde Yeniden Yaratılan Nostalji” bașlıklı araștırmaya dayandırılarak hazırlanmıștır. 
Bu çalışmanin amacı, Ankara’nın söz konusu tarihî bölgelerinde bu kültürün oluşumunu ve içinde barındirdiğı farklliklarl, nostalji kültürünü üreten aktörlerin mekân yaratma biçimleri üzerinden incelemektir. Çalı̧̧ma temel olarak, bölgede faaliyet gösteren kafe, restoran, antika dükkânl, sanat galerisi, sanat atölyesi, butik otel gibi işletmeleri ve müzeleri kapsayan saha çalıșmasına dayanarak toplumsal belleğin, geleneklerin, geçmişe dair algıların ve özlemlerin Ankara’nın kent kültüründeki yansımaların ortaya koymaktadır. Bu veriler ışı̆̆ında söz konusu üç bölgede farkl nostalji kültürlerinin oluştuğu ve oluşan kültürrün hem neo-liberal küreselleşmeden hem de Türkiyédeki hâkim siyasal dinamiklerden, özellikle son on yılda etkili olan neo-Osmanlıcllk politikasından etkilendiği görülmektedir. Anahtar sözcükler: Nostalji, Özgünlük, Estetikleştirme, Kentsel koruma, Kentsel dönüşüm, Kent kültürü, Hamamönü, Hamamarkası, Ankara kalesi, Ankara

\section{Introduction}

Ankara Castle and the neighbourhoods that surround it are areas frequently visited both by natives of Ankara and the tourists that come to the city as the places in which the oldest historic structures continue to exist. Some of these structures in Ankara Citadel which is administered by the Ministry of Culture and Tourism for being a protected area and in Hamamönü and Hamamarkasi which are administered by Altındağ Municipality, are restored and some of them were rebuilt according to their previous architecture. The shops, cafes, restaurants, museums and art institutions located in the region are mostly inspired by the traditional Turkish culture and history and provide goods and services that aim to revive the elements or the contemporary reflections of this history and culture. Therefore, it will not be incorrect to say that the region has become a centre of nostalgia of Ankara. The concept of nostalgia is central to explain the social transformation and dynamism that has been and will potentially be going on in the future and the ongoing dynamism in these neighbourhoods will continue to be shaped around this concept.

This article will elaborate the emergent and divergent nostalgia cultures in the historic sites of Ankara, particularly in the last two decades, through delineating how they are shaped in relation to claims of authenticity and aesthetics as well as urban conservation approaches. It will attempt to present the characteristics of the nostalgic spaces as an embodiment of historical and cultural references of the ties that the actors of the process have with the past. Taking neoliberal, nationalist, Islamist and Republican ideologies and politics as the major forces acting on the process, I specifically ask the following questions: Which social and political factors cause the differences in the urban regeneration processes among these three historic quarters and have a determining role in the current nostalgia scene? How are the notions of aesthetics, tradition, authenticity and cultural heritage utilized by the actors of the change as tools to justify and promote the current nostalgia scene and the stark spatial and social transformation that has taken place? How do urban regeneration projects function as a political tool by the incumbent local municipality to replace the previous deviant social textures with the politically and economically accepted/correct modes of city life? In exploring the answers, I aim to discuss the power relations and political claims embedded in what it presented to the urban visitors and tourists as "nostalgic" in the region.

The article is based on the fieldwork conducted in the historic centres of Ankara, Citadel (Kale), Hamamönü and Hamamarkası (Map 1. and 2). In-depth interviews and semi-structured surveys with the workers and owners of cafes, restaurants, boutique hotels, shops and museums in the region, observations in the public events comprise the fieldwork of the research. I started the fieldwork in October 2017 and having conducted 32 interviews in total, ended it in January 2018. 14 interviewees were from the Citadel, 10 interviewees were from Hamamönü and 7 interviewees were from Hamamarkası. Additionally, I photographed all the places in question and made a textual analysis of the websites and social media accounts of the institutions and the enterprises and the customer reviews on the Internet.

\section{Concepts to Read the Physical and Social Changes Taking Place}

When engaging in the task of understanding the urban culture in historic sites, the concept of nostalgia is clearly very central to elaborate on the relations of the current dwellers and visitors of the sites with the past. Nostalgia, a word made up of nostos meaning to return home and algia meaning longing in ancient Greek, is defined by 


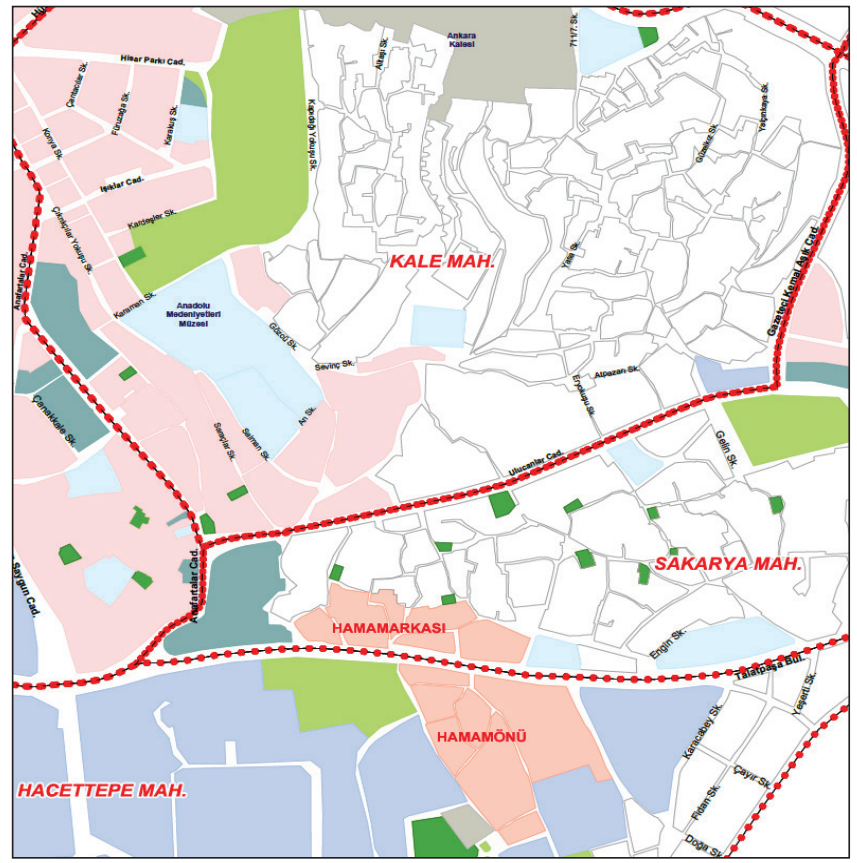

Map 1. Citadel, Hamamönü and Hamamarkası. Source: Altındağ Municipality, https://www.altindag.bel.tr/\#!haritalar.

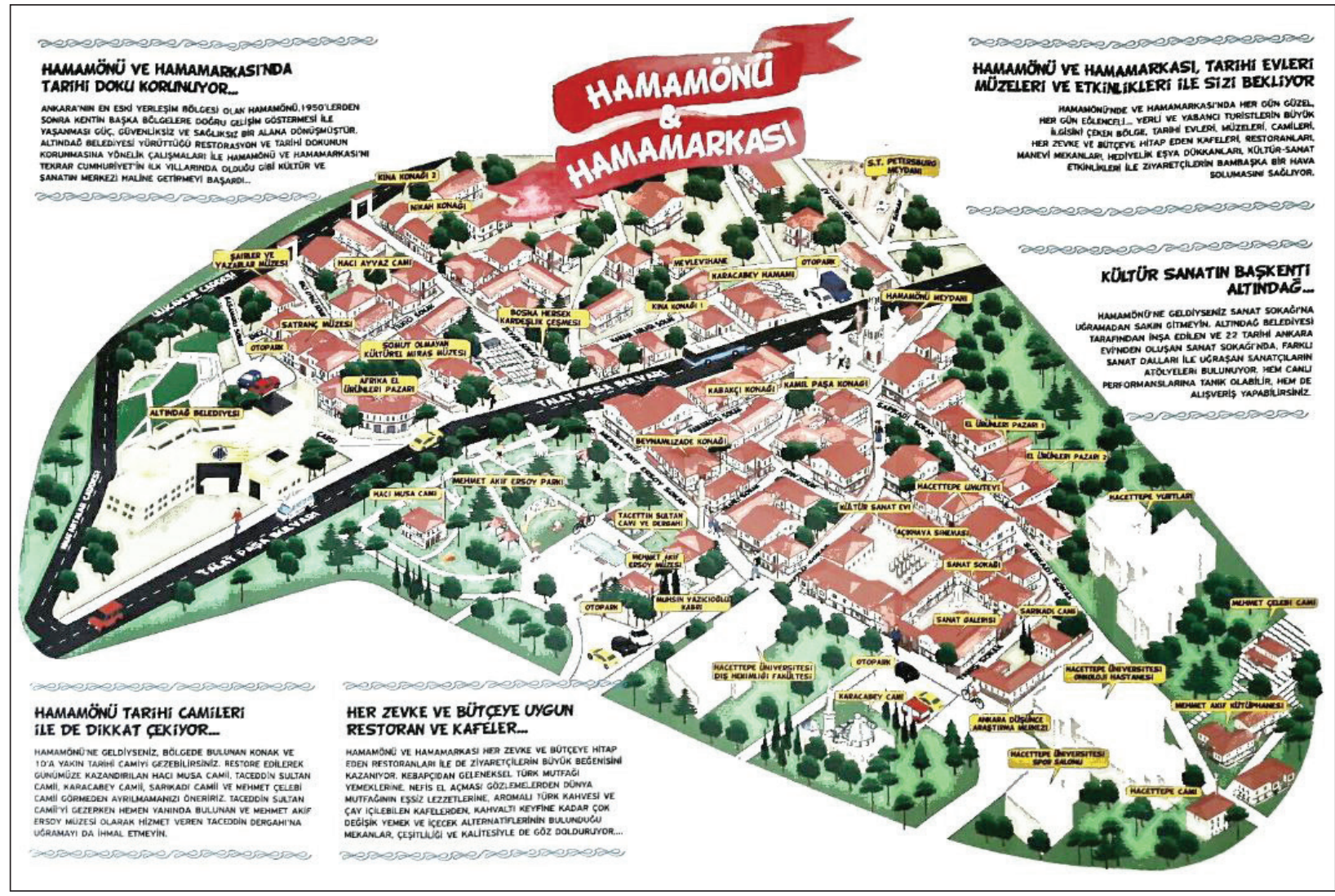

Map 2. Illustrative tourist map of Hamamönü and Hamamarkası. Source: Altındağ Municipality. 
Svetlana Boym in The Future of Nostalgia as "a longing for a home that no longer exists or has never existed. Nostalgia is a sentiment of loss and displacement, but it is also a romance with one's own fantasy." (Boym, 2001, Introduction, para. 4). While in the $17^{\text {th }}$ century it was considered as a curable sickness, mostly seen in soldiers who fought away from their homes, with the $20^{\text {th }}$ century it turned into "an incurable modern condition" against globalization, progress, and modernist utopias (2001, Introduction, para.5). A need for local attachments and "longing for a continuity in a fragmented world" has led to a rise in nostalgia (2001, Introduction, para.6). As Boym notes, nostalgia is beyond individual psychology and very much related to collective history and memory (2001, Introduction, para. 11).

Boym's conceptualization of nostalgia as restorative and reflective not only is very instrumental in understanding different collective approaches to cultural heritage but also allows us to address the differences between national memory which is founded on a single account of national identity and social memory, which comprises collective frameworks that influenceindividualmemory. Restorative nostalgia is characterized by its emphasis on nostos and aim to reconstruct the lost home. It considers itself as the absolute truth and tradition. Thus, it is no surprise that nationalist and religious revivals and invented traditions have this type of nostalgia in their essence (2001). Boym very importantly states that for those having restorative nostalgia "The past is not supposed to reveal any signs of decay; it has to be 'freshly painted' in its 'original image' and remain eternally young." (2001, Chapter 5, para.1). In contrast, reflective nostalgia flourishes in algia, meaning that it focuses on "longing and loss, the imperfect process of remembrance" (Chapter 4, para. 2). By considering the uncertainties of belonging it questions the absolute truth, rejects single plots of history, and dwells on details from the past and fragments of memory. It is important to note that for Boym, while restorative nostalgia is about rebuilding the past and constructing symbols, reflective nostalgia is very much about conserving the ruins of a lost home as they are and imagining various time zones.

The relations of power embedded in restorative nostalgia should be also thought with Jean Baudrillard's arguments on signs of power (Baudrillard, 2006). In his seminal work Simulacra and Simulations, Baudrillard argues that power produces its signs of resemblance and there is a significant collective demand for these signs. He continues that it is when there is a decline or disappearance of power that the demand for the signs of power increases:

When it has totally disappeared, we will logically be under the total hallucination of power -a haunting memory that is already in evidence in everywhere, expressing at once the compulsion to get rid of it (no one wants it anymore, everyone unloads it on everyone else) and the panicked nostalgia over its loss. The melancholy of societies without power: this has already stirred up fascism, that overdose of a strong referential in a society that cannot terminate its mourning. (Baudrillard, 2006, p. 23)

Following that he discusses what remains after the disappearance of power, namely the simulation of it and just as the economic law of supply and demand, he notes that the demand for signs of power will follow the same logic. In the absence of the violence and death caused by the power, these signs, like other commodities, are mass-produced and consumed in a world of a fiction of a political universe. (p. 26). Departing from Boym's restorative nostalgia, I would argue that we can take the invented traditions, constructed symbols, and rebuilt history as the signs of a domain of power that had existed in history. The increasing demand for these signs is very much associated with the mourning for the power that is lost and the supply and demand game is played according to the rules of contemporary neoliberal capitalism.

The second critical concept in understanding approaches to historic heritage sites is authenticity, particularly in the framework of tourism. The objectivist approach which was introduced by Dean MacCannell (1973) who wrote about staged authenticity in socially, historically and culturally important spaces as an outcome of commoditization of culture can be also associated with "museum authenticity" where objects are examined by an expert to evaluate their true nature (Laite \& Graburn, 2009 , p. 43). However, the rise of postmodernism calls this perspective into question and thus we encounter the constructivist approach. This approach claims that the attributed authenticity of things arises not from the fact that they are essentially authentic but from the fact that:

“... [T] hey are an invention of tradition' (Hobsbawm \& Ranger, 1983), or constructed through mediated meaning making, interpretation and agreement (Bruner, 1994; Hughes, 1995). In this case, authenticity becomes a projection of tourists' beliefs, expectations, 
preferences and stereotypes projected onto toured objects. (Wang, 1999). (Wang, 1999, cited in Zhu, 2012, p. 1497)

As Zhu also notes referring to Appadurai (1986) constructivism draws attention to the question of who has the authentication power, which should also be kept in mind when encountering the claims of authenticity in the historic sites.

The strict structuralism in the second approach gives rise to the questions about the agency of the actors. Wang (1999) develops existentialism in authenticity to imply a sense of "authentic self" linked with two categories: intrapersonal authenticity and interpersonal authenticity. The former refers to "the bodily feelings of relaxation of pleasure resulting from not being in contact with "authentic objects" but from engaging in nonordinary activities, free from constraints of daily life." (Zhu, 2012, p. 1498). In the latter one "tourists are driven by a desire for cultural exchange with "other", intensely authentic, natural and emotional interaction between friends, family members, or touristic communitas (Turner, 1967)" (Zhu, 2012, p. 1498). Zhu (2012) notes that Knudsen and Waade (2010) introduced the concept of performative authenticity, which brings a dynamic approach to the subject. It refers to a process of becoming authentic through an interaction between individual agency and the external world by means of an embodied practice. This approach is very relevant in understanding the experiences of the visitors of the historic sites and brings the analysis beyond the subject of the relationship between the historic spaces and people to a level of the subject of experiencing cultural heritages in those spaces.

Lastly, dwelling upon Sharon Zukin's discussion of gentrification, I consider aestheticisation as a central concept. The postmodern trend of transformation of old city centres into educated middle-class and artist neighbourhoods, not only supported historic conservation but also prioritised a new understanding of aesthetics in these sites. By the 1990s increasing emphasis on life-styles, the growth of the service sector, the emergence of alternative lifestyles, and the demand for high-quality goods has had an impact on urban culture. This has led the city governments to develop strategies to "to 'aestheticise' or focus on the visual consumption of, public spaces.” (Zukin, 1998, p. 825). Delving a little deeper than Zukin's use of the term in comprehending spatial aestheticisation necessitates addressing the ideological roots and use of aesthetics. Referring to Terry Eagleton's Ideology of the Aesthetic, Kanishka Goonewardena (2005) notes that "in order to be effective an ideology must be affective, that is to say aesthetic." (Goonewardena, 2005, p. 47) and he proposes the concept "urban sensorium" to refer to the city space "as a vital ingredient and the determinant of our 'sensate life', the traditional concern of aesthetics" (2005, p. 47). The author raises the question of the mediated relationship between ideology and space regarding "the gap between the sensible textures of the contemporary urbanism" and "the still more invisible and unrepresentable totality of global social relations", a question he believes, which needs to be discussed by geographers, architects and urban planners (p. 55). Aesthetics in the service of ideology is definitely a core dimension of both gentrification processes and urban regeneration projects. Even though both can be thought in relation to the repercussions of the global, middleclass consumption culture, I intend to demonstrate in the following sections that the latter can additionally be related to right-wing, nationalist ideologies. It is at this point that we encounter neoliberal urbanism. Noting that aestheticisation of politics, meaning "emergence of politics driven by aesthetic motivations, delineated by aesthetic concerns and/or masked by aesthetic appeals", is a critical element of neoliberalism, R. Alan Walks (2006) rightly argues that neoliberalism and aestheticisation work in cooperation for exclusionary strategies on the basis of class and identity (Walks, 2006, p. 466). Particularly, excluding lower class and minority populations from the aestheticised urban spaces not only create new contradictions but also magnify already existing ones.

Another approach to nostalgia that should also be associated with the conceptualizations of authenticity and aestheticisation above is by Jennifer Kitson and Kevin Mchugh (2015) according to which they dwell upon the concept of enchantment. Their contribution to the discussions on nostalgia is the integration of sensual effects and experiences arising from the contacts between bodies and things, the contacts which they describe as a kind of enchantment with the unbridgeable distance between past and the present (p. 490). They explain it as "Oscillating between feelings of distance (irretrievability of the past) and proximity (sensations felt in the present), nostalgia is the sensory experience of desire for something 
that is unnameable and unreachable, momentarily present in fleeting fragments" (p. 490). In their study on the dwellings in the historic neighbourhood Coronado, Arizona, they illustrate how nostalgic practices, performances and materiality create an everyday "aesthetic of pastness" (p. 488). The neighbourhood which appears as a group of architectural remnants that had been modified according to the demands and needs of the multiple generations who lived there, cannot be framed within a "singular narrative, history or a preservation code" (p. 502). And yet in this context, as Kitson and Mchugh argue, the inhabitants make use of history and preservation as a means for their "desire for sensual experience" of the past (p. 502).

Urban regeneration projects in historic sites of cities transform mostly the areas where the aforementioned concepts emerge as the key issues to consider. Urban regeneration is defined by Peter Roberts (2016) as "comprehensive and integrated vision and action which seeks to resolve urban problems and bring about a lasting economic, physical, social and environmental condition of an area that has been subject to change or offers opportunities for improvement" (Roberts, 2016, p. 18). As this definition infers and discussed by Leary and McCarthy (2013) urban regeneration is "multidisciplinary research, scholarship, public policy and practice, including elements of city planning, housing, transport/infrastructure, political economy, urban design, urban tourism, community development, sustainability, and cultural industry studies" (Leary and McCarthy, 2013, p. 6). Therefore, each related field has its own methodology, approach and definition and it is expectable that in the plethora of recent city literature disagreements arise. Leary and McCarthy argue that this is because the question of whether the conceptualization is based on "a normative or a positive position is left vague" (p. 9). Instead, they suggest that the definition needs to be exempt from the political and practical struggles and contradictions and offer a kind of ideal type which they call "aspirational regeneration", and define urban regeneration" as an "area-based intervention which is public sector initiated, funded, supported or inspired, aimed at producing significant sustainable improvements in the conditions of local people, communities and places suffering from aspects of deprivation, often multiple in nature.” (p. 9). While accepting the role of partnership public sector, they highlight the significance of public sector leadership in terms of providing funding, and "strategic vision and longevity" (p. 9). Yet, as it will be demonstrated in the following sections, the vision and action involved in the urban regeneration projects have been mostly shaped by political ideologies and market forces. This leads to a lack of interest in the negative social, cultural, economic and environmental consequences and complexities of the projects and an overemphasis on the aspired "urban renaissance" in the regenerated areas (Shaw and Porter, 2013, pp. 1-2). In the Middle Eastern context, neoliberalism plays a dominant role in the regeneration projects and in the Turkish context, political tendencies of governing institutions come to the fore as another determining factor. ${ }^{1}$ Thus, aestheticisation and authenticity in addition to traditions and cultural heritage are used as tools by local governments in regenerating historic sites, which had turned into areas of urban problems, in accordance with the ruling political agenda and neoliberal economy. The next section provides a framework of these dynamics at the national level.

\section{Approaches to Cultural Heritage in Turkey}

The phenomenon of conservation of historic city centres as cultural heritage and their transformation into tourist attraction spots is encountered in many cities around the world and has been the research subject of a plethora of studies in architecture, urban planning, geography, urban sociology, and the related fields. It is evident that conservation approaches and activities vary just like the historic structures do from one culture to another. Aylin Orbaşlı eloquently illustrates this point in her study on

1 Aylin Orbaşlı (2007) explains how old quarters of several cities in the Middle East, i.e. Medina, Mecca, and Isfahan (Fethi, 1993; Bianca, 2000; cited in Orbaşl1, 2007), have been victims of rapid capitalist urban regeneration processes. Amman's recent neoliberal character of urban regeneration projects are discussed by Eliana Abu-Hamdi (2016), and Rami Faruk Daher (2007)elaborates the urban conservation/regeneration projects in Jordan and Lebanon through highlighting the emerging roles of neoliberal capitalism, the role of aid agencies and international donors and the new agents of notable families and political elites. Regarding the Turkish case, Tuna Kuyucu (2018) exhibits how the role of the political relationship between the municipalities with the central government is influential in the successful implementation of urban regeneration projects. About the authoritatively exclusionary agenda of the projects, see Uysal (2011) and Uğurlu (2013) and the impact of neoliberal globalization, see Öktem (2006) and Günay (2018). 
the conservation works and approaches in Islamic cities (Orbaşl1, 2007). Noting that the conservation examples in Western Europe have sometimes an exaggerated tendency "to keep everything as it is", she explains that this approach may not be desirable for other cultures (p. 168). As she gives various examples from the Middle East as well as examples from the conservation and restoring works carried out in Turkey, Orbaşl 1 argues that there are three dimensions which need to be considered in urban tourism and conservation works of historic sites. The first one is the political decision-making processes that structure the development of tourism and conservation activities; the second one is the economic dimension that includes the activities serving tourism, and the third one is the social dimension regarding the relations between the visitors and the inhabitants of the historic sites. Regarding the political and economic dimensions, she gives examples of Soğukçeşme Street in Istanbul, the historic building surrounding the Mevlana Museum in Konya, historic town of Antalya, and the mansions in Ankara Citadel neighbourhood in Turkey where conservation applications reflect intentions of creating a "showpiece" for tourists while accommodating new functions to the built structures through making modifications in the original, traditional architecture (pp. 171-173). She also underlines that once historic city centres are restored and opened to tourism, old inhabitants have to move out because the rents become unaffordable. In the case of small historic towns, conservation projects open the daily lives of the inhabitants to the tourist gaze. Meanwhile, a new experience is offered to those tourists who seek the authenticity they lost in modern life. An outcome of this trend has been commercialization of hospitality, as clearly observed in Şirince Village, Izmir, Turkey ( $\mathrm{p}$. 174) or as in the Hatta Village of United Arab Emirates, traditional handicrafts are revitalized as financial motives in villages built in rural areas or cities to offer authentic experiences to tourists (pp. 178-179). She suggests that a balance needs to be established between the spatial, physical and social needs of the inhabitants of the historic sites and the expectations of the visitors in conservation projects (p. 185).

The subject of tourism and authenticity in Turkey is also discussed by Evrim Ölçer Özünel (2011). Like Orbaşl1, she states that the local and authentic cultural assets are replaced by "pseudo local" services and products. Moreover, she underlines that the created synthetic authenticity is internalized by everyone and integrated to the perceptions of identity, and argues that this process is an outcome of modernity which produces its spaces of authenticity and "re-produces the cultures consumed in these spaces" (p. 259).

The political dimension of heritage conservation approaches in Turkey needs a deeper elaboration. Edhem Eldem puts the issue as "subordination of the entire notion of heritage to political and ideological priorities" (Eldem, 2015, p. 67). He studies the period starting from the first attempts of Ottoman museology and archaeology in the second half of the nineteenth century to the present day by emphasizing the discrepancy between the western understanding of heritage conservation and nationalist concerns regarding the Turkish/Islamic/ Ottoman heritage. With the addition of Anatolian and Near Eastern civilizations to the constructions of Turkish ancestry, early Republican period added another dimension to this area for Eldem. He argues that since the 1980s increasing pressures of mass tourism and rising neo-Ottomanist and Islamist political tendencies started to be determining powers which have put great pressure on the cultural agenda of heritage conservation (pp. 67-68). Particularly during the recent years of the rule of the conservative Adalet ve Kalkinma Partisi (AKP Justice and Development Party), Turco-Islamic heritage and "reinvention of Ottoman Empire" have been given priority. Accompanied with foreign policy ideals of reestablishing the Ottoman supremacy in the region, neoOttomanism gained pace also in domestic politics and popular culture. Celebration of the glorified imperial past has been taking place through enactments of the conquest of Istanbul, popular TV series about Ottoman history, and modern replicas of "classical" Ottoman architecture, particularly mosques. As Eldem notes, influences of neoliberalism play a leading role in putting this agenda into effect (Eldem, p. 87). Regarding the entanglement of neoOttomanist nostalgia and neo-liberalism, Nora FisherOnar presents a similar argument in her analysis of "the politics of imagining Istanbul" (Fisher-Onar, 2018, p. 1). She compares two frames of Istanbul; namely Belle Époque in which the city is characterized by being the $19^{\text {th }}$ century cosmopolitan hub of the Empire and OttomanIslamic in which the city is imagined mostly in the time period from the rule of Mehmet the Conqueror (14321481) to the rule of Süleyman the Magnificent (14941566) characterized by conquers (pp. 3-4). As Fisher- 
Onar explains, these two frames of imperial nostalgia are used instrumentally by the municipalities, "each serves as a sort of municipal imaginary with nationallevel traction" (p. 5), though Ottoman-Islamic one is privileged. While "Belle Époque story appeals to liberal business people", "rising pro-religious business interests and intellectuals, on the other hand, tend to endorse the Ottoman-Islamic narrative" (p. 6). She also points that neo-imperial nostalgia's entanglement with globalization is a tendency not only specific to Istanbul but seen in other global cities such as Mumbai, Beirut and Shanghai (p. 5.).

\section{Ottoman and Republican History of the Region}

The historic centre of Ankara comprises Ankara Citadel and the neighbourhoods surrounding it, namely $\mathrm{Hac1}$ Bayram, Hamamönü, Hamamarakası, Hacettepe and Ulucanlar. Particularly Ankara Citadel is the oldest core of the city that hosted Galatian, Roman, Byzantine, Seljuk, and Ottoman civilizations before the foundation of the Turkish Republic. Hamamönü and Hamamarkası neighbourhoods, which receive their names from Karacabey Hamamı, Ottoman bath built in 1427. The neighbourhood in front of the hamam is called Hamamönü, and behind it is called Hamamarkası. The hamam was restored in 1988 and today it is one of the two historic hamams of Ankara which are still active. There are several Ottoman religious buildings in the region from the $15^{\text {th }}$ to the $19^{\text {th }}$ centuries. Because of the earthquake in 1892 and the great fire of 1917 that destroyed historic Ankara almost completely, the mansions and housing structures mostly date back to the $19^{\text {th }}$ and early $20^{\text {th }}$ centuries (Gültekin, 2014; Atauz, 2004). One of the most significant religious buildings in Hamamönü is the mosque, tomb and dervish convent of Taceddin-i Veli (Dergâh) built in the $17^{\text {th }}$ century. The mosques and other religious structures in the region are relatively small to serve a small number of local dwellers.

In the Ottoman era, especially from the $15^{\text {th }}$ century onwards, Ankara was a very significant trade city famous of its angora wool and precious sof textile made of angora. Located at the intersection of trade routes, most importantly the Silk Road, at the centre of Anatolia, Ankara had been a very prosperous and cosmopolitan trade city where a significant percentage of the city population was made up of European, Greek, and Armenian traders. However, by the $18^{\text {th }}$ century, the trade routes and the mode of production Europe were changing, and this led to a steady economic decline of the city and the cosmopolitan demographic structure started to change (Ergenç, 1980, 1982). By the $19^{\text {th }}$ century, the population and the daily life of Ankara were significantly more homogenous (Aktüre, 2004).

During the War of Independence (1919-1922) following the defeat of the Ottoman Empire in World War I, Ankara became the headquarter city. The first parliament of the new Turkish state was opened here in 1920 and after the war, it became the capital city of the secular Turkish Republic. In this period the region gained a new significance. The new bureaucrats of the Republic were among the dwellers of the historic region, the first foreign embassies were located here, and the new modern city started to be built around these neighbourhoods. In time, most of these dwellers moved to the new neighbourhoods, the city continued to enlarge and started to attract migrants from the surrounding cities. The initial city development plan of the German planner Hermann Jansen did not suggest any conservation applications of the historic centre and this region started to host the low-income migrant population seeking cheap housing. The migrants were changing or modifying the housing structures according to the needs of their families.

It was not until the 1980s that a conservation plan for the historic sites was developed. 1994 was the year that the Islamist Refah Partisi (Welfare Party) achieved a significant success in local elections and since then Ankara metropolitan city has been ruled by the conservative local governance of AKP. The implications of this change have been deeply felt in various aspects of city life, the repercussions of which are evident in the historic neighbourhoods of Ankara. ${ }^{2}$

\section{The Citadel}

The recent conservation history of Ankara Citadel and the historic neighbourhood within and surrounding its walls can be traced back to the 1980s, particularly the 1987 Conservation Plan. The transformation of this

2 For the implications of the political changes in local governance on urban planning, see S. Z. Şahin, 2007, The Politics of Urban Planning in Ankara between 1985 and 2005, unpublished doctoral thesis, Middle East Technical University, Graduate School of Social Sciences. 
region following this period has been comprehensively discussed by Asuman Türkün Erendil and Zuhal Ulusoy (2002) who suggest that the idea of conserving historic city centres and redesigning them for the aim of attracting tourism also means a redefinition of the authentic identities. They rightly suggest that this redefinition is determined within cultural, political, and ideological contexts and these aspects had not been discussed sufficiently until the 2000s. They draw attention to the fact that historical city centres are re-built in a way to meet the expectations of the global tourism industry and on the basis of its language and symbols (Erendil ve Ulusoy, 2002, s. 668). Erendil and Ulusoy propose that the project which won the urban conservation design project competition in 1987 for the only region in Ankara that more or less preserved its historic and traditional fabric is in line with this global tendency. The winning project suggested that old mansions in the region be transformed into bars and restaurants for upper-income groups and moe plain structures turned into hotels. As stated by the authors, even though the plans seemed like ideas for the revitalization of history and tradition in the city, they represented the standardization tendency of the global tourism industry. Besides, they also underline the fact that the new trade activities changed the modest mahalle (neighbourhood) identity in the region, and that the region has turned into a space where lower-class inhabitants and upper-class visitors curiously observe one another (p. 656). The region has also become a point of attraction for the suburban sections of the society who seek traditions and nostalgia thanks to the historical conservation and environmentalist movements ( $\mathrm{p}$. 655). The life of the inhabitants of the Citadel and the surrounding neighbourhoods stage authenticity for these tourists. Erendil and Ulusoy address this issue of encounters more elaborately in another writing where they state, "The role which is cast to the Citadel in this scenario is to set a stage where authenticity behind nostalgic tunes to adopt historical heritage particularly to the consumption demands of the relatively prosperous local and foreign visitors" (Erendil and Ulusoy, 2004, pp. 263-264). I would also like suggest further that the Citadel neighbourhood was transforming into a space of both intrapersonal authenticity where the visitors step away from their daily routines in the city and interpersonal authenticity where the visitors would engage in encounters with "other" cultures of Ankara.

Despite the fact that the 1987 Conservation Plan was hardly implemented due to various bureaucratic, economic, and legal handicaps, Erendil and Ulusoy are right to point out that the 1990s and early 2000s indeed became the heyday of tourism in the region. The first souvenir and handcarts shops, a few first-class tourist restaurants, art galleries, art studios and antique shops started to be opened in these years side by side with the relatively old shops and tea houses of the neighbourhood. In addition to the upper- and middle-class visitors from Ankara, foreign bureaucrats and their families living in the city and foreign tourists who usually visit Ankara on their way to Cappadocia in Nevşehir, Central Anatolia. Certainly, the location of the Anatolian Civilizations Museum right beside the entrance of the Citadel should be considered as an important factor in this.

The first significant NGO in Citadel was Geleneksel Türk El Sanatları Vakfı (Traditional Turkish Handicrafts Foundation - GESAV) opened in 1989. GESAV held exhibitions, organized training programmes for women particularly who lived in Citadel and sold handicrafts in their store. Initially, they pursued their activities at a historic mansion that the Ministry of Culture allocated them during the liberal governance of Anavatan Partisi (Motherland Party - ANAP). In 2008, when the Ministry (of the incumbent AKP government) terminated their agreement, they moved to another historic building in the Citadel given to the use of the foundation by one of the old families of the neighbourhood.

Zeynep ${ }^{3}$, a handicrafts shop and gallery owner in the region recounts her early days in the Citadel in 1998 as "a bloodstream from the leather workshops on the street was flowing as I was hosting foreign guests from an embassy". Explaining the primary motivation of her business as introducing authentic Turkish culture, history and arts to the foreigners, she became one of the few entrepreneurs who founded the Ankara Citadel Foundation (Ankara Kalesi Derneği) in 2003 to initiate an organized response to the local government's neglect of the region. In addition to explaining the demands

3 The names of the interviewees are pseudonyms. 
and suggestions of tradespeople to the municipality, the NGO also organized Citadel Fests for four years since 2007. The Foundation could not continue its activities due to several reasons including the problems among its members and lack of financial and bureaucratic support. Yet a new cultural milieu flourished, again with the initiatives of the relatively new art entrepreneurs of the Citadel. Recently, in cooperation with several other art galleries, antique shops and designers in the region, Zeynep began to organize an art festival each year in early March to attract more visitors.

At this point, it is crucial to note that these initial attempts and their contemporary repercussions of promoting the "authenticity" of the Citadel were driven by a secular Western Republican ideology. All of the interviewees who had been or are still part of these attempts are mostly highly educated middle and uppermiddle class professionals who strictly defend secularism and Westernization together with globalization and liberalism. They are willing to increase cultural interactions in the Citadel with foreigners, referring mainly to Europeans, Americans and the Japanese, defending a European approach in urban conservation, namely keeping everything "as it is" just like in major European cities. Besides, they are highly critical of the prevalent Islamist neoliberal agenda of the government, disappointed about the attempts or neglect of conservative local governments to underpin their efforts for -what they believe to be-ideological reasons and are mourning for the weakening ideals of the Republican era. Last but not least, they underline that there is a patriotic mission in their endeavours, a mission which is a remnant of early Republican patriotism. All in all, their understanding of urban aesthetics is inspired by modern Western cities and their understanding of tradition and authenticity is mostly based on a secularized vision of Turkish history and culture. Therefore, these social and political characteristics and the cultural capital of the group, members of whom can be defined as the actors of the changes taking place in the Citadel neighbourhood have been highly determining factors in the emerging nostalgia culture. Thus, the spatial representations of their relations with the past and longings for a lost home should be comprehended on this basis.

In terms of local governance, the impacts of the conservative attitude of Ankara Metropolitan Municipality and local Altındağ Municipality -which are in line with the Islamist-nationalist agenda of the AKP governments- have been felt in the neighbourhood more intensely since 2010. Cancelling or not renewing licences to sell alcoholic beverages, unwillingness to solve infrastructure problems (lack of natural gas pipelines for instance), prolonged street constructions, lack of security especially at night, and lack of street lighting has led to a decrease in the number of tourists and several popular restaurants to close down or reduce their capacities. Lacking a comprehensive long-term conservation and cultural investment plans except some street rehabilitations that are highly inconsistent with the traditional architectural texture and restoring in the facades of the old buildings, the current urban culture in the neighbourhood is the product of the individual initiatives of the shops, cafés, restaurants, art studios, galleries and hotels, most of which struggle to conserve the remnants of the historic texture of the region. Reflective nostalgia, in the sense that Boym (2001) uses, suffuses almost all fragments of urban culture in the Citadel. When these fragments are considered as a whole, they actually comprise the pieces of a counter nostalgia culture against the prevailing modern reconstructions of history.

Nostalgic atmosphere of the region firstly arises from the sensual experience in these places. The smoky smell which surrounds the Citadel like a cloud in winter, in fact, an outcome of the lacking natural gas infrastructure, disperses from the stoves lit in every building. On every stove there is a teapot and roasted chestnuts offered to friends, visitors and customers. This scene is very common for large sections of the middle-aged and elderly segments of Turkish society in their childhood memories. This power of stove which stimulates all the senses bridges childhood with the present time and makes stove the centre of the home nostalgia. During winter, it is very common to see the customers of the cafés heating themselves around the stove as they recall their childhood homes. The sensual experience can definitely be described as an "enchantment" that Kitson and Mchugh (2015) conceptualize in relation to their understanding of nostalgia. This should also be considered as performative authenticity (Knudsen and Waade, 2010) through which the visitors of the historic region experience the atmosphere of traditional wooden houses and visualize the pre-modern life that had been lived there. 
Several antique shops that the visitors encounter in their walks through the streets surrounding the Citadel exhibit another face of the nostalgia culture, which is also spread to many other places in the region. The most prominent feature of the cafés, restaurants and boutique hotels is that their very much home-like decorations are full of antique or old furniture and objects (Figures 1 and 2). As a café owner Şevket noted, everyone in the Citadel was a collector first and then they started a business there. He also started collecting locks and keys after he opened his café. A boutique hotel owner Hasan had been collecting porcelain dolls and Ottoman clothes before and now he exhibits some pieces of his collections at the café of the hotel. A café famous of its gramophone and record

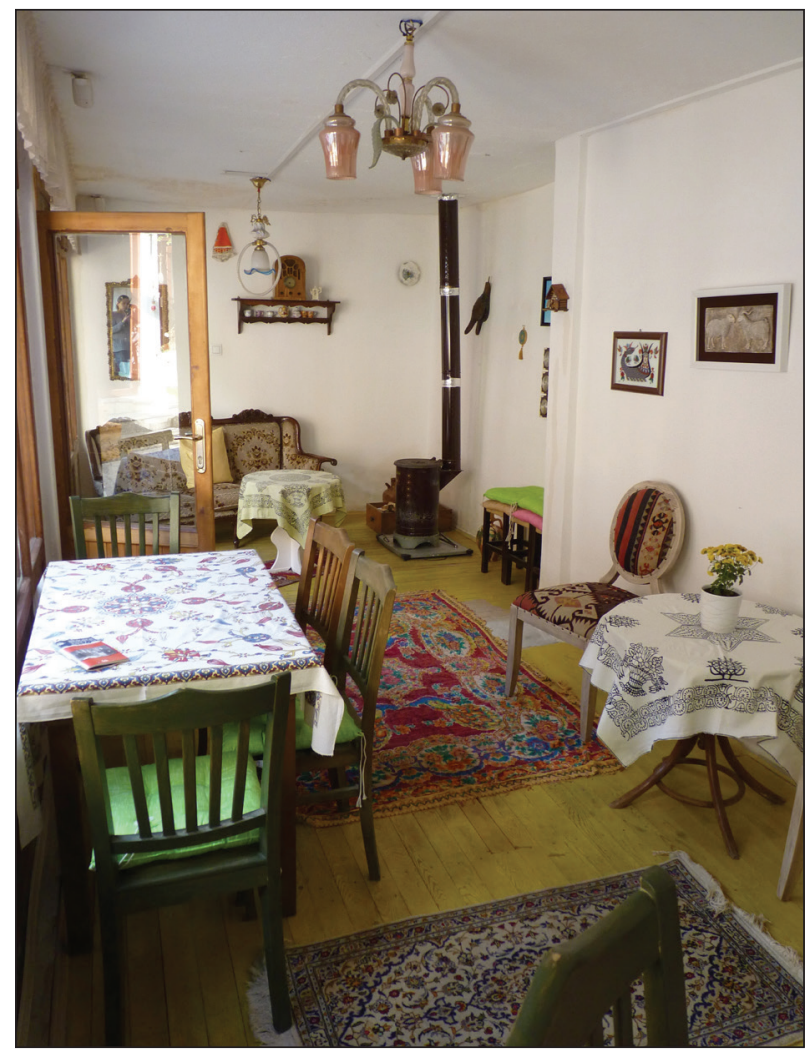

Figure 1. A café in the Citadel. Source: Photograph by author. collection was opened by an entrepreneur who had worked in the gramophone repair shop at the historic Pirinç $\mathrm{Han}^{4}$ in the Citadel neighbourhood. It is not only that these records and gramophones accompany a tea break or a breakfast table of the customers, but they are also exhibited as imageries that will trigger the imaginations and memories of the urban travellers who find themselves in reflective nostalgia in their journeys back to their childhood homes. Besides the individual collectors, Rahmi Koç Industry Museum founded in historic Çengel Han in 2005 has become a significant tourist spot, a centre of objective authenticity, and an embodiment of an institutional approach to reflective nostalgia. ${ }^{5}$ Since its foundation, it has achieved a significant number of

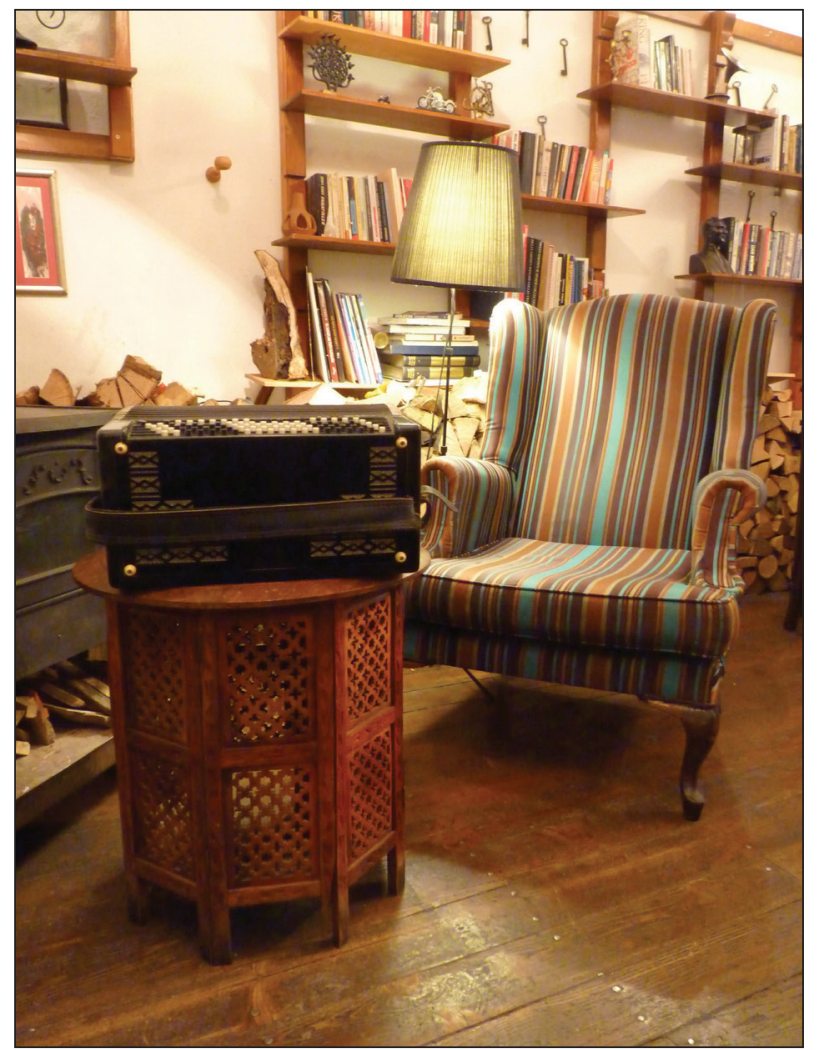

Figure 2. A café in the Citadel.

Source: Photograph by author.

4 Pirinç Han is an historic caravanserai built among the others (Çengel Han, Mahmut Paşa Bazaar, Çukur Han, Kurşunlu Han, Pilavoğlu Han, Sulu Han, Zafran Han) in the region in the $16^{\text {th }}$ century and early $17^{\text {th }}$ century when the Ottoman Empire and the trade in Ankara were at their zeniths to accommodate merchants and their caravans (2008, Ulusla Buluşma II: Hanlar Bölgesi, Sergi Kataloğu, VEKAM). The building was restored in 1991 and its rooms started to be hired as antique shops and art and handicrafts studios.

5 The significance of the museum building also arises from its recent history. One of the pioneering industrialists in Turkey, the owner of Koç Holding and the father of Rahmi Koç, Vehbi Koç used to have his first shop in Çengel Han. A replica of the shop is also exhibited in the museum. 
Turkish and foreign visitors and played an important role in educating younger generations about industrial history. Mesmerised with all the objects he sees in the museum, a pre-schooler donating his old Play Station, which is currently exhibited on the ground floor, is an anecdote that illustrates this role.

Certainly, the regulations regarding urban conservation in the Citadel and its surroundings allow only limited changes in the buildings. Yet, it seems that business managers and the artists who have become the new owners or tenants of the buildings show a great respect to the historic textures and they find peace with it. For instance, Pilavoğlu Han which no longer functions as a caravanserai and has opened its rooms to artists and collectors is a space where exactly this sense of history prevails. There is even a design studio inside that uses used wood pieces from old buildings and furniture in its designs. If we again refer to Boym's concept of reflective nostalgia, we can easily state that we look for our home in the ruins of the past and get even closer to it in these spaces. This must be the reason that when the new owners of a café which recently changed hands suggested painting the pale walls, the previous owner told them "don't paint them, the place is beautiful as it is" and they agreed. The painter Kemal Çelik, who currently works in his studio in historic Pirinç Han has been painting every street and building of the Citadel since he arrived in Ankara in 1959 (Figure 3). He calls this region "my Ankara" because of the same emotional bond and the desire to preserve.

When asked about the reference point or the historical inspirations of their longings of the past, most of the interviewees in the Citadel mentioned early Republican Ankara, even describing the period as the golden years of the city, and a few answers were mentioning pre-Islamic civilizations of Anatolia. These answers demonstrate the secular association embedded in the reflective nostalgia

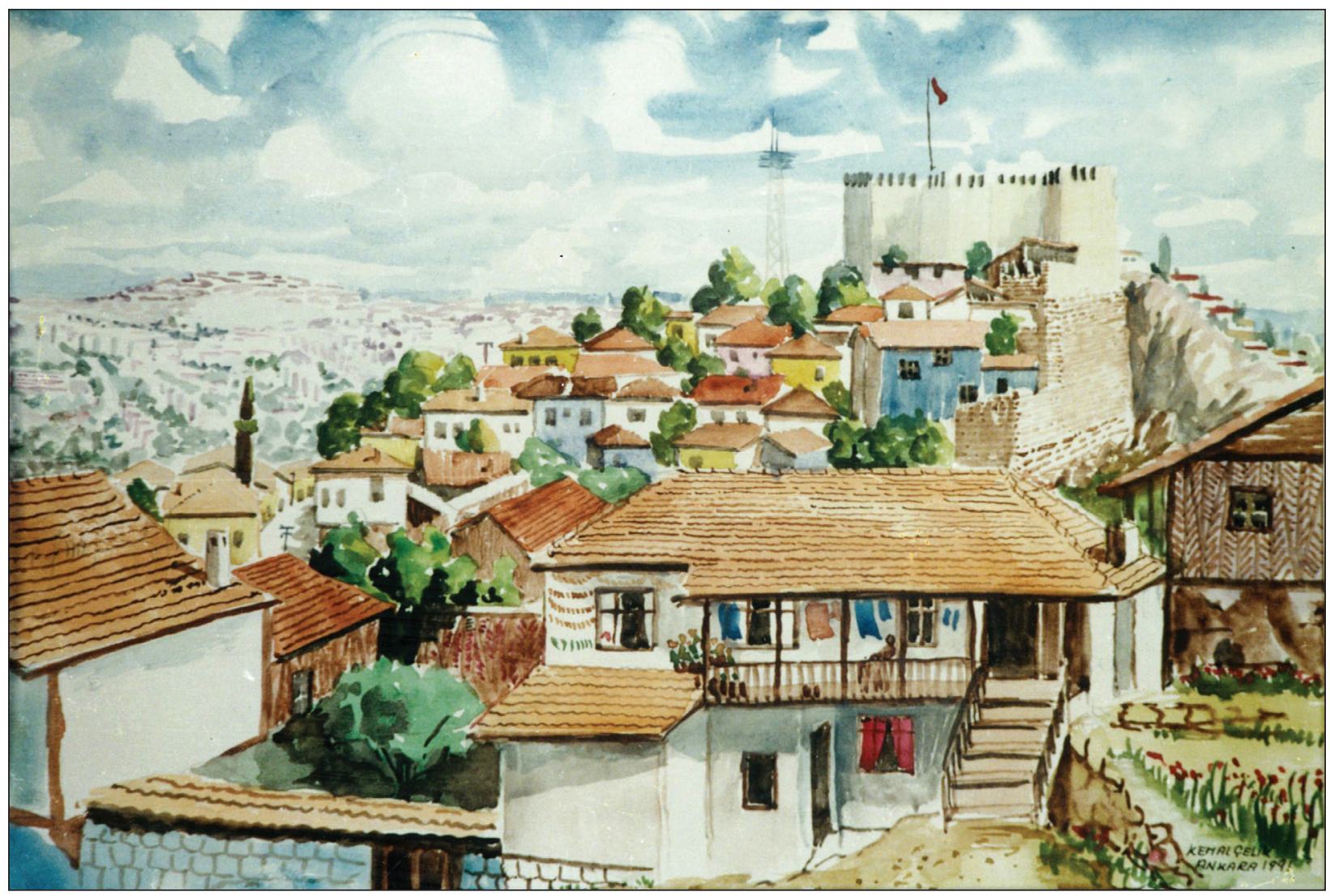

Figure 3. “The Citadel”, Kemal Çelik, 1991.

Source: Archive of the artist. 
culture. The nature of the aestheticisation process of the Citadel is closely linked with a secular, Westernist, Republican ideology which aspires a European understanding of urban conservation and implies an oppositional political stand against the reconstructive nature of the Ottoman-Islamic nostalgia prevalent in Hamamönü and Hamamarkası.

\section{Hamamönü Regeneration and Restoration Project and the Current Nostalgia Culture}

Hamamönü regeneration and restoration project is one of the most famous urban regeneration projects in Turkey. The low-income neighbourhood infamous of its high crime rates was a region that outsiders were scared to pass by has turned into a tourist spot through a radical upgrading-rehabilitation project carried out by Altındağ Municipality (Figure 4). The mayor Veysel Tiryaki, from conservative AKP, put great emphasis on this project besides his other urban regeneration projects transforming gecekondu (slum) areas into areas of mass housing blocks. The Hamamönü project, which started in 2006, involved street rehabilitation projects, reconstructions, restorations, renewal and reformations, restorations of historical mosques and building parks (Gültekin, 2014). Most of the previous residents of the area had to leave their houses because of the urban regeneration and the rising housing prices. In the restored buildings, new cafés, patisseries and kebab restaurants were opened. Besides, several NGOs with conservative agendas moved their offices to this region. The aestheticisation of the neighbourhood was achieved through a process that literally cleared the previous social structure in every means. It is important to note that one of the largest faculties of medicine in Turkey, Hacettepe University Faculty of Medicine and Hospital is neighbouring Hamamönü and a large number of students, academic and other faculty staff, patients and their relatives have been the customers of the small cafés,

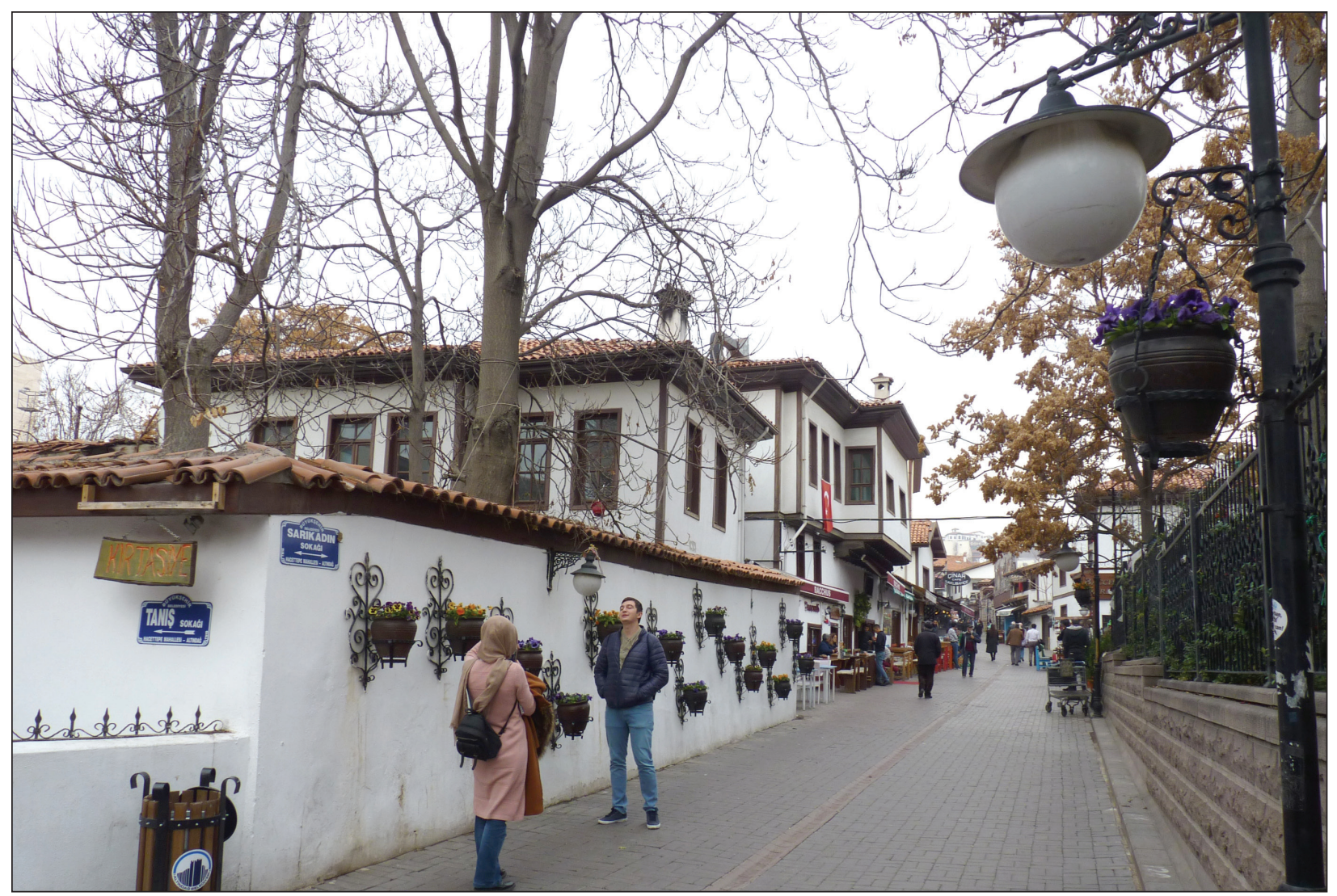

Figure 4: A street view of Hamamönü, Sarıkadın Str.

Source: Photograph by author. 
stores and tea houses of the neighbourhood since the 1950s.

The new urban culture in the neighbourhood is largely shaped and determined by the Municipality through both explicit and subtle means. The great advertising campaign of the urban regeneration in Hamamönü emphasized the re-vitalization of history that involved claims of authenticity. It is very much evident in the public events of Ramadan Fests and Hamamönü Talks which it organizes that the historical reference point is essentially Turco-Islamist and Ottomanist. During Ramadan, all the streets of Hamamönü are turned into a booth area where visitors can buy various local products and handicrafts, and can have their photographs taken in Ottoman sultan costumes. In the evening, after iftar ${ }^{6}$, traditional Sufi music and plays from traditional Turkish folk theatre are performed on the stage set in the main square of Hamamarkası. The second group of public events of the Municipality is Hamamönü Talks in which it organizes at a restored mansion, Kabakçı Konağ17. These are public gatherings of NGOs, most of which hold Islamist, nationalist, neo-Ottomanist views, with invited speakers talking mainly on the subjects of politics, national history, and Islamic and Turkish culture. More subtle means of changing the urban culture of the neighbourhood can be understood in the ways the restored buildings were allocated to their new owners or tenants. A considerable number of them have personal ties with Tiryaki and have conservative worldviews.

At this point, the historical, cultural, and spiritual significance of Taceddin-i Veli (1590-1680), also known as Taceddin Sultan, Mosque and the Dervish Convent should be taken into account. He was the leader of his dervish order in Ankara. He lived in the dervish convent which was built as a social complex from early $17^{\text {th }}$ century until he died. He was such a loved religious leader and poet that even the dwellers of his neighbourhood were exempt from taxes. The complex was restored in 1901 by Sultan Abdülhamid II. The selamlik house of the convent is also the place where the poet Mehmet Akif Ersoy wrote the lyrics of the Turkish national anthem. The complex was a very crucial part of the urban regeneration project. The houses and the historic tomb building were restored. The selamlik house was restored as Mehmet Akif Ersoy House and a park was built around the buildings. In recent history, this Islamic complex gained a new significance. Muhsin Yazıcıoglu, one of the most popular nationalist-Islamist political leaders in Turkey was buried in the cemetery of the mosque after he died in a suspicious helicopter accident in 2009. For these three reasons, Taceddin Mosque has always been attracting visitors from all around Turkey. It is no coincidence that the office building of Gönüllerde Birlik Vakf (Unity in Hearts Association), the NGO founded to disperse the ideas of Yazıcıoğlu is a restored mansion in Hamamönü. Besides, in the fieldwork several interviewees who were café owners, waiters and artists mentioned that they used to come here even before 2006 to visit the tombs of Taceddin Sultan and Muhsin Yazıcıoğlu. This implies the attractive force of the spiritual centre of Hamamönü which has been influential in the formation of the current social and economic networks.

The economic activities in the rehabilitated streets are dominated by cafés, patisseries and restaurants. Some of these were established long before the urban regeneration for serving their customers from Hacettepe Faculty of Medicine. After 2006 they redecorated their buildings and began to serve also the new visitors exploring the region. The Municipality does not give liquor and nargile ${ }^{8}$ licences to the restaurants and cafés here. Ali, the owner of three cafés in Hamamönü, has been the first entrepreneur to serve Turkish coffee made on a semi-traditional brazier. His first café was mainly about revitalizing the traditional Turkish coffee culture and upon the large demand it received, he opened other branches and started to serve other popular foods and beverages. Meanwhile, his brazier became so popular that all the other cafés started to have one (Figure 5,6). He explains that in 2006 and 2007, large numbers of educated middle-class people from various parts of Ankara came to visit this newly restored historical site and looked for authentic places to eat and drink. However, the cafés and restaurants were not prepared for these customers -they increased their prices but could not increase the quality of service and food. Besides, all they could serve

6 Iftar is the fast breaking time in Ramadan.

7 Konak is a large mansion in traditional Turkish architecture.

8 Nargile: hookah 
was fast-food and breakfast. Disappointed with the loss of authenticity in the region and opportunism of the enterprises, this new group of visitors did not return. "It is all our fault. We did it all together. I admit" says Ali. Today, it is still almost impossible to find local cuisine in Hamamönü. Pasta, French fries, waffles, sandwiches, cheesecakes, grilled chicken and meatballs, and gözleme ${ }^{9}$ are the sine-qua-non of many cafés.

One book-café located in Art Street, right opposite of the historic Sarı Kadı Mosque stands out as an exception to other cafés. The name of the café is a term used for the educational institute of the Ottoman palace. It is owned by three pious women ${ }^{10}$ who had dreamt of opening their place while taking Islamic art courses in a studio in the Citadel neighbourhood. The waiters and the cook are also women. Their home-like hospitality is perpetuated with the menu. The pastries, salads and snacks mostly cooked and baked at home by women for guests are served at relatively low prices. In contrast to others in Hamamönü, the café is busy throughout the day. Medicine students, mostly pious ones who go to the mosque to pray, and students of an Arabic course given at an NGO next to the mosque spend the time here between their courses and prayers. Even their parents come to the café to thank the owners for providing such a "safe" place for their children. All in all, this place restores a home nostalgia surrounded by traditional family values and an Islamic atmosphere.

The urban scene in Hamamönü clearly illustrates Boym's conceptualization of restorative nostalgia both physically and culturally. The previously colourful built environment is painted in white just as the historical mahalle ${ }^{11}$ culture is erased by liberal tourism activities. While the history was being rebuilt, freshly painted, aestheticised and exhibited for the visual consumption of the new urban tourists, the once multi-cultural social structure and the Republican history of the neighbourhood were ignored, omitted, and/or destroyed.

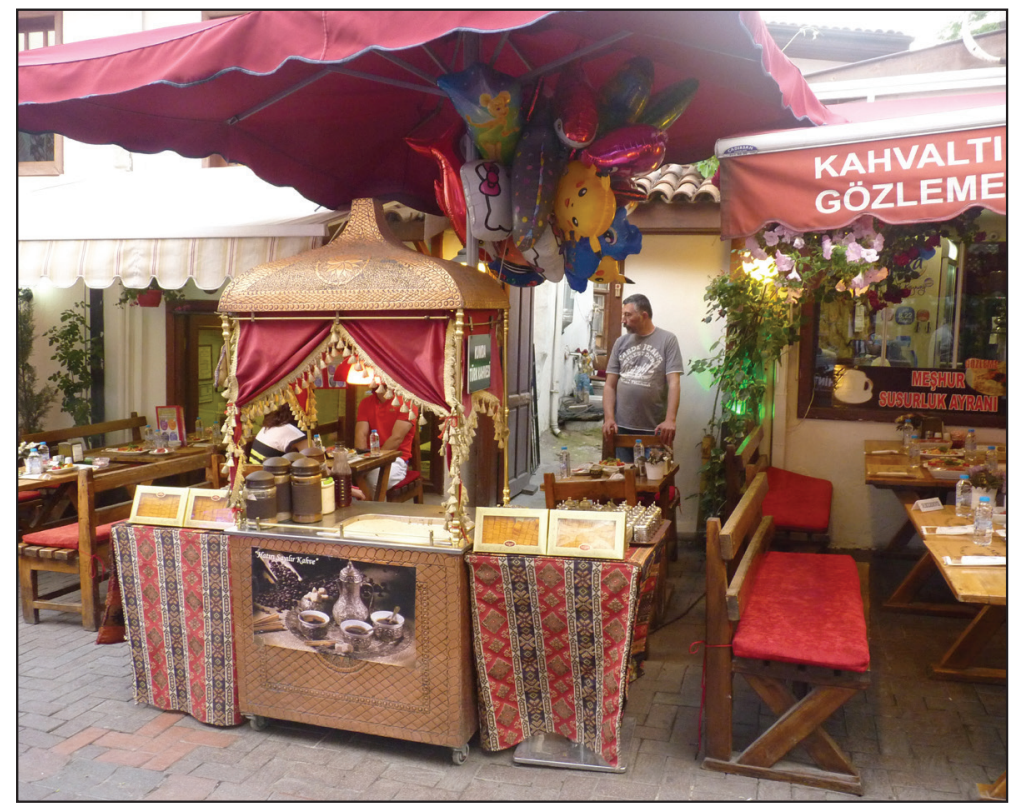

Figure 5. The coffee and café culture in Hamamönü. Source: Photograph by author.

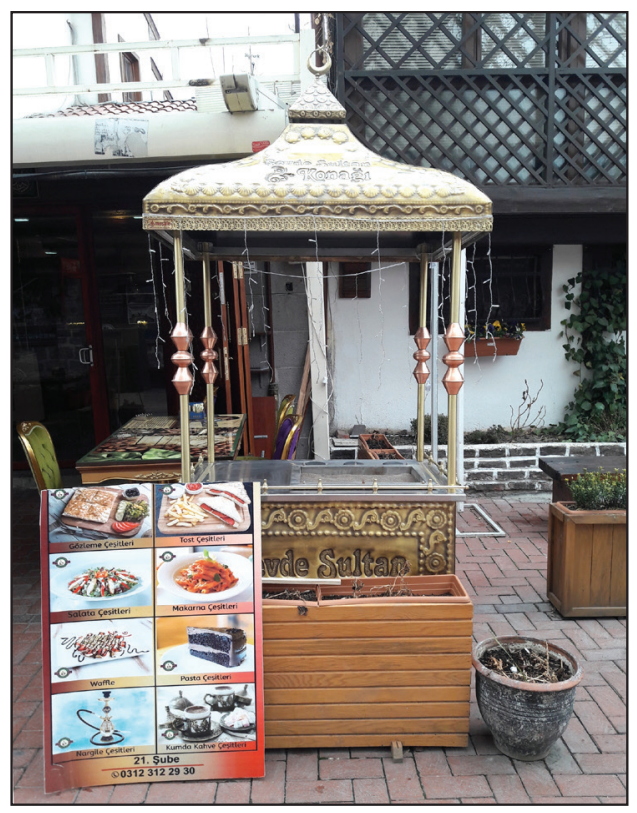

Figure 6. Turkish coffee brazier in Hamamönü.

9 Turkish salty pancakes mostly filled with cheese, meat, potatoes, or spinach.

10 One of these women is a well-known Islamist writer/columnist who had also published an Islamist women's magazine. She knows Veysel Tiryaki in person.

11 Mahalle literally means neighbourhood in Turkish but it refers to a dense network of social relations among its dwellers. It is traditionally neither a public space nor private space but a semi-public one in between. 
For the sake of clearing everything and every place that could pose a threat to security, the notion of the mahalle was destroyed and an ideally moral urban space was created. The legitimation of this clean-up is in the return to the imagined Ottoman-Islamic roots. Besides, despite all these efforts of the Municipality, some café owners do not agree that the streets of Hamamönü are safe now. Ali told about some incidences between the young men coming from the nearby low-income neighbourhoods and the young people from middle-income families, in which the former verbally or sometimes physically attack the latter. He added that he and other cafés have difficulty in finding waiters because of the security problems in the evening. Thus, it is evident that by rehabilitating the area, the Municipality sent away some social issues to other areas of the city and since they remain unresolved, they continue to haunt Hamamönü.

The case of urban regeneration projects in this district is a very apparent example of the use of aesthetics, in the way Goonewardena (2005) discusses, and authenticity in building spaces of mainly two ideologies, namely TurkoIslamism and neoliberal capitalism. For the realization of both, excluding previous low-income social groups was regarded as a necessary step. Then it became possible for the Municipality to build new spaces of nostalgia where the prevalent agendas of the AKP based on Turko-Islamist and neo-Ottomanist ideologies could be presented in an aestheticised form. This also involved a selective use of history which excludes the multi-ethnic, multi-cultural as well as Republican history of Hamamönü. The presence and the religious significance of Tacettin Dergâhı is a facilitating and uniting factor in the formation of the current social networks of Hamamönü. The second ideology is the neoliberal capitalism, embodied in the cafés which attempt to aestheticise an experience of historical authenticity through serving Turkish coffee on the one hand and all kinds of popular Western (fast) food for the customer demand on the other. The way the Municipality regulates the trade activities draws the limits of authenticity in forbidding alcohol and nargile to preserve an Islamic morality and does not deal with the overabundance of non-authentic goods and services provided for the visitors. Authenticity in Hamamönü is created through a mediated meaning making among the Municipality, the enterprises in the region and the demands of the visitors, all of which are yet in line with the restorative nostalgia that symbolizes a homogenous, unilateral Turkish Muslim history.

\section{Hamamarkası Regeneration Project and the Current Nostalgia Culture}

Upon the success of the Hamamönü, the Municipality started to implement its second regeneration and rehabilitation project in Hamamarkası in 2012. Before regeneration, the neighbourhood shared similar social and cultural characteristics with Hamamönü. However, the conservation approach of the Municipality radically changed. This time the project involved an almost complete reconstruction of the neighbourhood, old houses were demolished, and new 'old houses' were designed and built to serve functions other than housing (Figure 7). The city planner, urban sociologist and political scientist Savaş Zafer Şahin, who had also worked in the Hamamönü project, states, "This time the Municipality crossed the line" and describes the new historical sites as "model history of Ankara" (Şahin, 2016). When we look at which social and cultural features replaced the old neighbourhood, we mostly see henna houses, museums, cafés, offices of Islamist politicians and NGOs, and a few shops and Islamic art studios, three of which deserve special attention.

The henna ceremony is one of the Turkish wedding traditions for brides. A few days before the wedding, the bride and female relatives and friends from both families gather in the evening in the bride's home, and eat, sing and dance and colour their hands with henna, which symbolizes that the bride is ready to sacrifice herself for her husband and children. ${ }^{12}$ If the bride cries during the henna ceremony, it is believed that her tears will bring good luck. The henna tradition was outdated in the social history of modernization, especially in the cities. However, together with the rise of conservatism and the flourishing wedding market, it was almost reborn in the 2000s, and hotels and restaurants started to host henna nights. For some brides, it even turned into a bachelorette party. Some of the new 'old mansions' of Hamamarkasi started to function as henna houses and became their first kind in Turkey. Lale, a wedding organizer and a

12 The reddish colour of henna resembles blood and symbolizes sacrifice. In Turkish culture there are two other occasions where henna is used. On the animal to be sacrificed for Islamic reasons and in the palms of young men before they are sent to their military service. 
henna house owner states that their place became highly popular and has been attracting brides from even uppermiddle class neighbourhoods of Ankara who normally have no intention to come to this part of the city. She says that throughout the wedding season the main square of Hamamarkası is very crowded and lively, "like Kizılay", the city centre. The common atmosphere and style in most of the henna houses are very much Ottoman. The influence of harem decorations in popular TV series about Suleyman the Magnificent, The Magnificent Century is highly noticeable. Lale enthusiastically explained to me how she was impressed by the series and decorated the henna house just like that harem on TV. In another henna house, replicas of the war helmets of Süleyman the Magnificent is part of the highly glamorous decoration in golden colours (Figures 8, 9). In both houses, there is a flamboyant throne for the bride to sit. Instead of the traditional bindall ${ }^{13}$, Ottoman kaftans in various colours and designs are offered to the bride by the henna houses. Lale designs the kaftans herself.

The impact of the rise of neo-Ottomanism in popular culture has been highly noticeable in Turkey in the last five years, and henna houses are just a small manifestation of its popularity, yet they should not be underestimated. The tradition in itself perpetuates, normalizes and even exalts gender inequality. Its entanglement with Ottomanism carries it to another level where authoritative masculinity is exalted, and women are assumed to be contented with glamour.

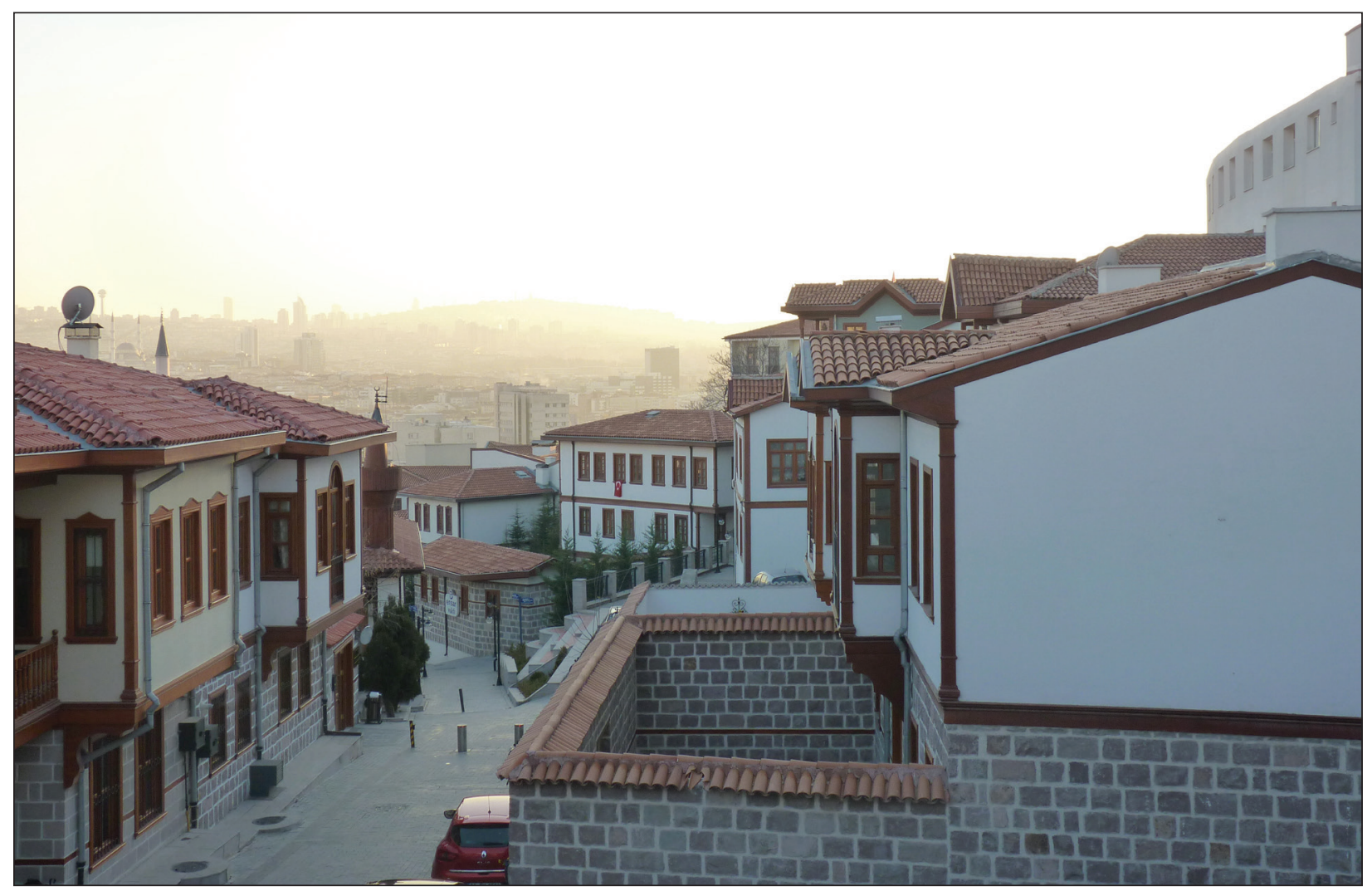

Figure 7. A view of Hamamarkası. Source: Photograph by author.

13 The long, colourful jacket inlaid with silver or golden threads worn by the bride in the henna night. 
There are three museums in Hamamarkasi: Intangible Cultural Heritage Museum (Somut Olmayan Kültürel Miras Müzesi), Poets and Authors House (Sairler ve Yazarlar Evi), and Gökyay Foundation Chess Museum (Gökyay Vakfı Satranç Müzesi). The first two are very relevant in terms of their contributions to the urban culture of the region. Intangible Cultural Heritage Museum is founded by Gazi University, Department of Folklore in 2013 and administered by the students of the department on a voluntary basis. The museum is spatially organized to show and illustrate its visitors how it used to be to live in a traditional Ankara house. Additionally, there are rooms where the students from the department perform traditional Turkish performing arts and demonstrate traditional Turkish performance arts, such as Karagöz shadow plays and puppet plays, and handicrafts, such as copper work, weaving, and textile wood printing. The guides accompany each visitor and explain in detail the culture vitalized in the museum. Almost every day, the museum receives student groups from schools. Hasan, the director of the museum who is a graduate student at the Folklore Department, noted that they have an academic approach in the museum, they continuously conduct research about the intangible cultural heritage of Ankara and its surroundings, and illustrate their findings in the museum. The museum's activities go beyond the spatial boundaries when they organize traditional Hidirellez festivals each year to celebrate the arrival of summer in cooperation with the Municipality in Hamamönü. Their objectivist approach

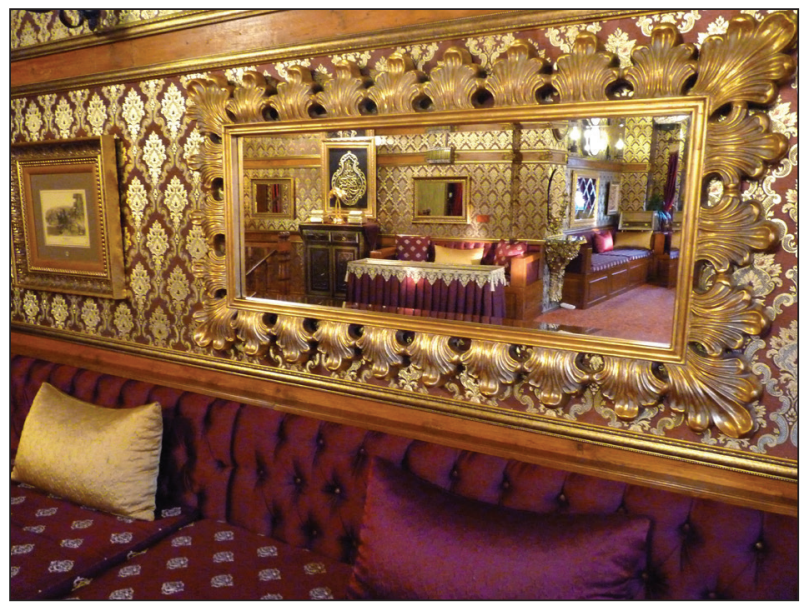

Figure 8. A henna house in Hamamarkası. Source: Photograph by author. to authenticity is more than evident, however, Selcan Gürçayır Teke's article on these festivals in Hamamönü also has a point in saying that various traditions are re-interpreted and popularized by the organizers (Teke, 2016). On the other hand, they also invite their visitors to experience performative authenticity both in the museum in traditions handicrafts workshop and children's playroom and in their festivals.

The second museum was founded by a former deputy of AKP and a poet. Ahmet is an agricultural engineer who worked as a teacher, a civil servant, and a bureaucrat for many years while engaging in poetry and literature. $\mathrm{He}$ was a former director of Turkish Authors Union. When I asked about the story of the museum he said that he always wanted to establish a literature museum and had asked for the support of the metropolitan municipality from the former mayor of Ankara in 2007. Even though the mayor agreed, there weren't any attempts afterwards. In 2015, he heard that one of his poems was being read on the radio by Veysel Tiryaki, and Ahmet immediately contacted him. Learning that Tiryaki was one of the fans of his poetry, Ahmet asked his support to establish the museum, and finally, one of the rebuilt mansions in Hamamarkası was allocated for the Poets and Authors House. Biographies, books, and some personal belongings of the authors and poets who lived in Ankara in the Republican period are exhibited in the museum. Besides, Ahmet organizes public literature talks on Saturday afternoons in the museum, starting after the afternoon prayer and ending before the evening prayer,

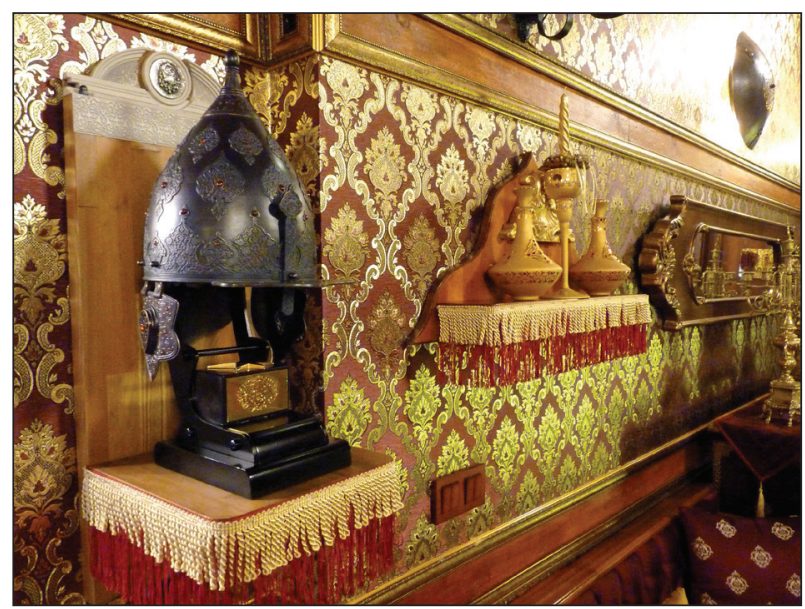

Figure 9. A replica of the helmet of Süleyman the Magnificent. Source: Photograph by author. 
and each week introduces and discusses the poems of a different poet. The audience consists mostly of university students and high school literature teachers. In the two meetings that I attended as a listener, he introduced poets who are very popular among Islamist circles in Turkey. Perhaps because of his teaching background, the talks are mostly in a didactic format. The spatial organization of the room, where the listener stools are placed beside the walls and Ahmet's desk is placed in front of the room, in the middle, also support the format. He actually noted that he designed the room in a way to resemble the classrooms in the Ottoman period. The scope of the talks went beyond literature from time to time and extended to theology and the listeners also participated with their questions and comments about Islamic belief. Ahmet deeply admires Sezai Karakoç who is one of the most significant poets and philosophers of Islamism in Turkey and Ahmet regards him as his elder brother. Ahmet knows several other well-known Islamist poets in person and supports his ideas in the talks with his personal memories. His sermon-like lectures are clearly very influential on some with Islamic motivations in the audience. A literature museum gains an Islamist character which has a sense of nostalgia of its own. Longing for the Golden Age of Islam or recent political history of Turkey when Islamist movements started to gain a momentum is very dominant. Poetry is comprehended within this framework.

Right opposite of the museum there is the law office of one of the founders and former ministers of AKP. In our first meeting, Ahmet mentioned that the next literature talk may take place at this office if he would have time to make a speech -but he was not in Ankara that weekend. Next to that office, there is the building of an Islamist literature journal and down the street there is the office of another former minister of AKP. On one of my field visits, I saw another former AKP minister going out of the literary journal's building. Certainly, this clustering is not a coincidence. The group of former politicians of AKP who have opened offices here after they left the party were called the "Hamamönü Movement" in 2016 and many newspapers wrote that the leader of the group was the former president and one of the founders of AKP Abdullah Gül, the $11^{\text {th }}$ President of Turkey (2007-2014) who now wanted to form a new political party. Beyond the political rumours, the social network of former AKP members is significant for displaying the embodiment of the underlying political forces acting on the urban culture in the region.

In addition to Boym's (2001) framework of restorative nostalgia, Baudrillard's discussion of nostalgia on the basis of the increasing supply and demand for the signs of power where the actual power no longer exists is also a very relevant lens to read Hamamarkasi. It is clear that the urban regeneration project is an illustration of restorative nostalgia, the one that aims to re-create and revitalize the past on the basis of an imagined Ottoman history and in accordance with the AKP's nationalist and religious politics. Besides, particularly in the case of henna houses, it is possible to observe that the signs of the glory of the empire, which disappeared a long time ago, is supplied, demanded and consumed in a fiction intertwined with contemporary politics, popular culture and urban culture. Aesthetics in the "new old" architecture of the neighbourhood and the decorations of the interior spaces serve to popularize the dominant Turko-Islamist ideology. In the impossibility of a physical sense of authenticity and history, what the neighbourhood offers is an interpersonal authenticity enabling the visitors from the modern city life to get in contact with an imagined Islamic and Ottoman culture.

The unfinished story of Hamamönü and Hamamarkası neighbourhoods demonstrates that the political, social and cultural agenda and priorities of the Municipality have been highly determining in the urban regeneration in question. The cultural heritage of the region crystallized in the Taceddin Sultan Dervish Convent is reflected in the various facets of the nostalgia culture. The selective approach in re-vitalization of history which excludes multiculturalism and secularism should also be read as another manifestation of the deep social divide between Islamists and secularists. In this region, social and political networks and economic relations give way to a conservative city culture, in other contexts, other social and political networks did and do produce other fragments of culture.

Certainly, we need to ask whether the times when all these spaces where the longing for feeling at home is satisfied to a certain degree were real "homes" is left way behind. What have we lost irreversibly with restorations, as the buildings changed hands and what kind of a home are we looking for now? The recent Hamamarkası housing project of Altındağ Municipality seems to be developed 
to address these questions. Tiryaki, introducing the new project comprising 60 houses all designed by himself, states

It is going to be a mahalle having the old texture that matches the horizontal architecture. (...) Everyone wants to use them as offices, we don't want this. We want people who will live here, who will reside here. (...) This place will reflect mahalle culture. In a mahalle, everyone controls one another, no problems arise, no robbery occurs. In a place that you call mahalle, you cannot reside if your neighbours do not allow you to. (Ankara'dan Haber, 2018)

Tiryaki contrasts the ideal image, this nostalgia of mahalle with the contemporary high-rise apartment blocks in housing estates and their modern individualist life-styles distant from nature. It is evident that this upcoming part of the Hamamarkası urban regeneration project is imagined to be a reconstruction of a lost home represented in use of the term mahalle in Tiryaki's words. It signifies a reconstruction of close community ties, higher social control and an exalted traditional family life, much in line with the ideology behind AKP policies. Thus, behind this restorative nostalgia, the use of tradition, urban aesthetics and cultural heritage serve to promote a conservative city life which is a fundamental aspect of local governance understanding of AKP.

\section{Result}

By attributing a central place to the role of nostalgia, this article aimed to focus on and analyse the contemporary urban culture in the three main historic neighbourhoods of Ankara: Citadel, Hamamönü and Hamamarkası. I perceived and described the divergent nostalgia cultures in these neighbourhoods as outcomes of the different uses of aestheticisation, authenticity as well as traditions resulting from neoliberal, nationalist and Islamic ideologies on the one hand, and secular Republican ideology on the other hand. In the Citadel region, the oldest one among the three and a conservation site, reflective nostalgia is very much prevalent in various aspects of its contemporary urban culture. In the absence of a comprehensive urban regeneration project, the change taking place in the region can be observed in fragments of municipality's street rehabilitation projects, attempts of private entrepreneurs, and some civil initiatives to revitalize a social life. The profiles of private investors and small entrepreneurs, who are mostly secular, Westernist, Republican, educated middle and upper-middle class people relay the main characteristic of the nostalgia culture, which I regard as reflective nostalgia. In their yearning for a lost home, which they see in early Republican Ankara, they have a tendency to keep the remnants of history in their original form. Their use of history, aesthetics, and authenticity in creating a nostalgia culture is shaped on this ground and should be considered as an attempt to produce a counter-culture against the dominant reconstructive use of history in contemporary Turko-Islamist politics and governance of the ruling AKP.

In contrast to the Citadel region, the recent nostalgia culture in Hamamönü and Hamamarkası is an outcome of urban regeneration projects of Altındağ Municipality, which rapidly and radically changed the social and spatial structure of these two neighbourhoods. Previously known with social problems of crime, poverty and urban degeneration, firstly Hamamönü and then Hamamarkası became targets of regeneration projects aiming to replace the previous neighbourhood with a new touristic site. Together with a neoliberal perspective, the nationalist, Islamist political standpoint of the Municipality and the historical and spiritual significance of the region arising from Taceddin Sultan Dervish Convent, Mehmet Akif Ersoy House and the grave of Muhsin Yazıcioğlu work in cooperation in creating a restorative nostalgia. While the Municipality has been supporting the cultural aspect of the regeneration process by organizing events and festivals which are mainly associated with an imagined Turko-Islamic and Ottoman heritage, the worldviews of the small entrepreneurs, NGOs and other institutions in the region is very much nationalist and Islamist. Therefore, the cultural atmosphere of new tourist sites is dominantly under the influence of all these factors and can be read as the embodiment of the actors' ties with an idealized Turkish-Ottoman history. The use of aesthetics is predominantly inspired by the glorious era of the Ottoman Empire, which I take as a repercussion of AKP's ideology of neo-Ottomanism. When it comes to authenticity, while the Hamamönü project had some intention to conserve only the architectural heritage, the Hamamarkasi project did not have any concerns about this issue. Thus, all we have about authenticity in these two regions is mostly the remnants of an imagined Ottoman heritage offered for tourists' and visitors' consumption. Thus, I argue that these regeneration 
projects which have replaced the previous deviant social textures with the politically and economically accepted/ correct modes of city life resulted in the formation of a full-fledged restorative nostalgia culture.

All these cultural and architectural transformations, building and rebuilding processes in the historic core of the city suggest that nostalgia in Ankara cannot be more dynamic and multi-faceted. As this article attempted to exhibit and discuss, the cases of urban conservation, restoration and regeneration in the Citadel, Hamamönü and Hamamarkasi and the emergent nostalgia cultures comprise critical political and ideological driving forces that give a particular characteristic to the urban culture of each neighbourhood. Given the parallel tendencies between the dominant political landscape of the country and the attitudes of local governance, reading urban regeneration projects and other transformations in Turkey, especially in historic districts, evokes thoughts and trigger discussions on how history, aesthetics, and nostalgia are used to provide popularity as well as new ground of legitimacy to the ruling ideologies. What my endeavour in scrutinizing nostalgia cultures of Ankara hopes to achieve is to provoke thoughts for further studies in the fields of urban sociology, city planning and architecture about the relations between ideology, power and productions of space embedded in the sweeping trends of remembering and/or revitalizing history in Turkey. Certainly, it is also necessary to analyse these trends in comparison with the contemporary trends in other post-imperial cities in the world.

\section{References}

Abu-Hamdi, E. (2016). The Jordan Gate Towers of Amman: surrendering public space to build a Neoliberal Ruin. International Journal of Islamic Architecture, 5(1), 73-101.

Aktüre, S. (2004). 1830'dan 1930'a kadar Ankara'da gündelik yaşam. In Güven Tunç, Figen Özbay, et. al. (Ed.s). Şehrin zulasi: Ankara Kalesi (pp.35-74), İstanbul: İletișim.

Altındağ Belediyesi (2018) Altındă̆ İlçe Haritası, from Altındağ Municipality web site. https://www.altindag.bel. tr/\#!haritalar

Altındağ Belediyesi (2014) Hamamönü \& Hamamarkast Haritası. Ankara.

Ankara'dan Haber (2018), Hamamarkasi'nda yeni bir mahalle. Accessed on 01.04.2018 from http://www.ankaradanhaber. com/ankara-haberleri/hamamarkasinda-yeni-bir-mahalle -h20539.html
Atauz, A. (2004). Kale ve Sur: Ankara'nın Kal'ası. In Güven Tunç, Figen Özbay, et. al. (Ed.s). Şehrin zulası: Ankara Kalesi (pp. 61-221), İstanbul: İletişim.

Baudrillard, J. (2006). Simulacra and simulation, Michigan: The University of Michigan Press.

Boym, S. (2001). The Future of nostalgia, New York: Basic Books, Amazon Kindle E-Book Edition.

Daher, R.F. (2007).Tourism, heritage and urban transformations in Jordan and Lebanon: Emerging actors and global-local juxtapositions. In R. F. Daher (Ed.) Tourism in the Middle East: Continuity, change and transformation (pp. 263-307), Clevedon: Channel View.

Eldem, E. (2015). Cultural heritage in Turkey: An eminently political matter. In Essays on heritage, tourism and society, Proceedings of the International Heritage Conference 2013 at Tangier, Morocco, (pp. 67-92), Paderborn, Germany, Ferdinand Schöningh.

Erendil, A. T., \& Ulusoy, Z. (2002). Reinvention of tradition as an urban image: the case of Ankara Citadel, Environment and Planning B: Planning and Design, 29(5), 655-672.

Erendil, A. T, Ulusoy, Z. (2004). İronik karşılaşmalar: Kale'nin entle ve kentin Kale'yle iki karşlaşması. In Güven Tunç, Figen Özbay, et. al. (Ed.s). Şehrin zulası: Ankara Kalesi (pp.221-286), İstanbul: İletişim.

Ergenç, Ö. (1980). XVII. Yüzyllın Başlarında Ankara’nın Yerleşim Durumu Üzerine Bazı Bilgiler. Osmanlı Araştırmaları, 1(1), 85-108.

Ergenç, Ö. (1982). Osmanlı Klasik Dönemindeki Eşraf ve Ayan Üzerine Bazı Bilgiler. Osmanlı Araștırmaları, 3(3), 105-118.

Fisher-Onar, N. (2018). Between neo-Ottomanism and neoliberalism. In N. Fisher-Onar, S. C. Pierce, and E. F. Keyman (Ed.s), Istanbul: Living with difference in a global city (pp.1-21), Rutgers, The State University.

Goonewardena, K. (2005). The urban sensorium: Space, ideology and the aestheticization of politics. Antipode, $37(1), 46-71$.

Gültekin, N. (2014). Urban Conservation Policy: The Case of Hamamönü - Ankara - Turkey. 54 $4^{\text {th }}$ Congress of the European Regional Science Association: "Regional development \& globalisation: Best practices", 26-29 August 2014, St. Petersburg, Russia.

Günay, Z. (2018). A critical appraisal on Turkey's neoliberal quest of urban renewal in historic urban landscapes. In J. H. Kruh, R. Adhikari and U. E. Dorka (Ed.s) Living Under the Threat of Earthquakes (pp. 129-141). Springer, E-book.

Kitson, J., McHugh, K. (2015). Historic enchantmentsmaterializing nostalgia, Cultural Geographies, 22(3), 487508. 
Knudsen, B. T., Waade, A. M. (2010). Performative Authenticity in Tourism and Spatial Experience: Rethinking Relations Between Travel, Place and Emotion (pp.1-19). In B. T. Knudsen, A. M. Waade (Ed.s) Re-investing authenticity: Tourism, place and emotions, Buffalo, Bristol, Toronto: Channel View Publications.

Kuyucu, T. (2018). Politics of urban regeneration in Turkey: Possibilities and limits of municipal regeneration initiatives in a highly centralized country. Urban Geography, 1-25.

Leary, M. E., McCarthy, J. (2013). Introduction: urban regeneration, a global phenomenon. In M. E., Leary, J. McCarthy, (Eds.). The Routledge companion to urban regeneration. (pp. 1-15) Oxon, New York: Routledge.

Leite, N., \& Graburn, N. (2009). Anthropological interventions in tourism studies. In T. Jamal \& M. Robinson (Ed.s) The Sage handbook of tourism studies (pp. 35-64), London, California, New Delhi, Singapore: Sage.

MacCannell, D. (1973).Staged authenticity: Arrangements of social space in tourist settings. American Journal of Sociology, 79(3), 589-603.

Orbaşlı, A. (2007). The 'Islamic'city and tourism: Managing conservation and tourism in traditional neighbourhoods. In R. F. Daher (Ed.)Tourism in the Middle East: Continuity, change and transformation (pp. 161-187), Clevedon: Channel View.

Öktem, B. (2006). Neoliberal Küreselleșmenin Kentlerde İnșası: AKP'nin Küresel Kent Söylemi ve İstanbul'un Kentsel Dönüșüm Projeleri. Planlama, 53.

Özünel, E. Ö. (2011). Kültür turizminde “yöresel” ve "otantik” olanı sorgulamak ve tüketilmiş mekânları yeniden üretmek üzerine, Turkish Studies: International Periodical for the Languages, Literature, and History of Turcic or Turkish, 6(4), 255-262.

Roberts, P. (2016) Revolution, definition and purpose of urban regeneration. In P. Roberts, H. Sykes, \& R. Granger, (Eds.). Urban regeneration. (pp. 9-43). London, California, New Delhi, Singapore: Sage
Shaw, K and Porter L. (2013). Introduction. In L., Porter, and K. Shaw, (Eds.). Whose Urban Renaissance?: An international comparison of urban regeneration strategies. (pp. 1-8). Oxon, New York: Routledge.

Şahin, Z. S. (2007). The Politics of Urban Planning in Ankara between 1985 and 2005. Unpublished doctoral thesis, Middle East Technical University, Graduate School of Social Sciences.

(2016). Ankara'nın maket tarih devri ve UNESCO. Accessed on 25.01.2018 from https://sehrekustu.blogspot.com. tr/2016/06/ankaranin-maket-tarih-devri-ve-unesco.html.

Teke, S. G. (2016). "Değişen kültürel mekânlar, dönüşen gelenekler: Ankara'da Hıdırellez kutlamaları ve Hamamönü Hıdırellez Şenlikleri”, Ankara Araştırmaları Dergisi, 4(1), 44-59.

Uğurlu, Ö. (2013). Dönüşen Kentlerde Çingene Olmak: İzmit Örneği/Being A Gipsy in Transforming Cities: The İzmit Case.Mülkiye Dergisi, 37(1), 71-104.

Ulusla Buluşma II: Hanlar Bölgesi. (2008) Sergi Kataloğu, Ankara: VEKAM.

Uysal, Ü. E. (2012). An urban social movement challenging urban regeneration: The case of Sulukule, Istanbul. Cities, 29(1), 12-22.

Walks, R. A. (2006). Aestheticization and the cultural contradictions of neoliberal (sub) urbanism. Cultural Geographies, 13(3), 466-475.

Wang, N. (1999). Rethinking authenticity in tourism experience. Annals of tourism research, 26(2), 349-370.

Zhu, Y. 2012. "Performing heritage: Rethinking authenticity in tourism”, Annals of Tourism Research, 39(3), 1495-1513.

Zukin, S. (1998). "Urban lifestyles: diversity and standardisation in spaces of consumption”, Urban Studies, 35(5-6), 825-839. 